\title{
EchoGéo
}

$48 \mid 2019$

Illegal cannabis cultivation in the world

\section{A brief agricultural history of cannabis in Africa, from prehistory to canna-colony}

Chris S. Duvall

\section{(2) OpenEdition}

12 Journals

\section{Electronic version}

URL: https://journals.openedition.org/echogeo/17599

DOI: 10.4000/echogeo.17599

ISSN: 1963-1197

\section{Publisher}

Pôle de recherche pour l'organisation et la diffusion de l'information géographique (CNRS UMR 8586)

\section{Electronic reference}

Chris S. Duvall, "A brief agricultural history of cannabis in Africa, from prehistory to canna-colony", EchoGéo [Online], 48 | 2019, Online since 13 July 2019, connection on 31 July 2021. URL: http:// journals.openedition.org/echogeo/17599; DOl: https://doi.org/10.4000/echogeo.17599

This text was automatically generated on 31 July 2021.

EchoGéo est mis à disposition selon les termes de la licence Creative Commons Attribution - Pas d'Utilisation Commerciale - Pas de Modification 4.0 International (CC BY-NC-ND) 


\title{
A brief agricultural history of cannabis in Africa, from prehistory to canna-colony
}

\author{
Chris S. Duvall
}

\section{Introduction}

1 Since the 1990s, the international drug-control regime has begun to crumble as societies have decided that drug prohibitions produce more problems than benefits (Bewley-Taylor et al., 2014; Bewley-Taylor and Jelsma, 2012). Cannabis has been a prominent focus of drug-policy reform. Many jurisdictions, especially in Europe, North America, and South America, have liberalized controls on cannabis by decriminalizing and/or legalizing some instances of production, sales, possession, and use. African countries are also participating in this global wave of cannabis liberalization.

2 Cannabis is an important crop in Africa. African farmers produce enough to meet demand on the continent and to export small quantities to Europe (United Nations Office on Drugs and Crime, 2018). Cannabis is not significantly imported into the continent, but international trading is common within Africa due to variations in supply, demand, law enforcement, and other farming opportunities. The crop provides income in rural communities, and to those who distribute and sell it in cities (Bloomer, 2008; Kepe, 2003; Léonard, 1998; Afsahi, 2014; Laudati, 2016). Cannabis is widely a cash crop for poor farmers where legal agriculture has become economically or ecologically untenable (Carrier and Klantschnig, 2016; Laniel, 2006; Perez and Laniel, 2004). In some countries, cannabis is a major national commodity with well-organized, if illegal, institutions of production, distribution, and marketing (Suckling, 2016; Laudati, 2014; Chouvy, 2008).

3 Questions about cannabis liberalization in Africa are inevitably agricultural even if farming is overlooked in national drug policies (see Kalunta-Crumpton, 2015). African countries have diverse interests, but agriculture is central to most national economies 
and economic development is a widespread priority. Scholars have argued that a strategy to advance economic development could be to allow farmers legal access to domestic and/or international markets for cannabis (Buxton, 2006, 2015; Zurayk, 2013; Laudati, 2014). Economic arguments for cannabis liberalization have been strong in other parts of the world, and strengthened by the revenues generated since 2014 in legalized markets in several U.S. states and Canada.

Current cannabis economies - in Africa and elsewhere - are fraught with social inequity, political-economic violence, and environmental degradation (Buxton, 2015; Zurayk, 2013; Johnson, 2017; Pontes Fraga and Iulianelli, 2011; Laudati, 2014, 2016; Chouvy, 2008; Carrier and Klantschnig, 2016; Bloomer, 2009; Kepe, 2003). Such problems are targets of explanation in the field of political ecology, in which humanenvironment interactions are viewed as simultaneously natural and social events (Robbins, 2011). In political ecology, historical analysis helps expose process-structure linkages within current interactions (Offen, 2004). In this article, I summarize the history of cannabis agriculture in Africa, in order to identify the foundations and trajectory of cannabis-centered economies. I outline four phases in this agricultural history: the mostly prehistoric period in which the plant initially colonized the continent; the brief period when cannabis was legal under colonial governments; the remainder of the twentieth century, when drug-control laws made it an illegal crop; and the currently unfolding moment when several countries have enacted cannabis liberalization.

5 I analyze African cannabis history based upon elements of political economic theory. I argue that current processes of cannabis liberalization are, with one exception, instances of accumulation through dispossession (Harvey, 2004) by Global Northern companies, enabled through the exercise of neocolonial power (Nkrumah, 1965; Langan, 2018). Seven African governments have authorized limited instances of cannabis farming. Six of these governments have loosened their cannabis controls to promote agricultural development. However, cannabis-centered 'development' is but a new facet of economic dependency, of wealth generation in the Global North through the extraction of wealth from Africa (Smith, 1997; Taylor, 2016). Historically, taxation of cannabis (i.e. primitive accumulation: Harvey, 2004, p.11-12) as well as the imposition of cannabis prohibitions under colonial and postcolonial regimes foreclosed opportunities to profit legally. Currently, African governments and Global Northern companies are together accumulating wealth by dispossessing the citizens of these countries of access to the increasingly legal, global cannabis economy. Cannabis policy reforms in the Global North have allowed legal wealth generation by private companies and publicly traded corporations. These businesses have paid African governments for policies that allow them to cultivate cannabis for export, through the payment of licensing fees that are too expensive for most citizens of the countries to pay.

6 Given the entrenchment of North-South inequity in the global economy (Nkrumah, 1965; Rodney, 2018 [1972]; Smith, 1997), it is unsurprising that the increasingly legal cannabis economy has unfolded unevenly. Neocolonialism has impeded wealth generation in multiple economic sectors in African countries (Haag, 2011; Hagmann and Reyntjiens, 2016; Langan, 2018; Taylor, 2019), and the recent phenomenon of land acquisition through long-term leases (i.e. land grabbing) is commonly interpreted as accumulation through dispossession, enabled through neocolonial power (Fairbairn, 2013; Ince, 2014; Liberti, 2013; Robertson and Pinstrup-Anderson, 2010). 
7 Nonetheless, it is necessary to situate cannabis in this context, for three reasons. First, the legal, global cannabis economy is new, having arisen principally since 2017. It has been cheered as a new avenue for development, but empirical evidence on cannabis history illuminates that cannabis-centered 'development' has instead only extended a pathway of economic dependence into a new sector. The case of cannabis suggests the enduring influence of colonialism, while underscoring the neocolonial power of Global Northern businesses (Langan, 2018). Second, cannabis-policy reforms in the Global North have global political-economic meaning, and are not simply precedents for how states might manage drugs within their borders. There is a risk of producing an apolitical ecology (Robbins, 2011) regarding the international significance of Northern cannabis reforms, even as political ecologies of drugs are recognized on national levels (Aggarwal, 2013; Aggarwal et al., 2012; Johnson, 2017; Rhodes, 2009). Reforms that have produced legal economies in the Global North have directly involved cannabis consumers in processes that disadvantage people in the Global South. Cannabis must be situated in the colonial past and neocolonial present to preclude apolitical ecologies that neglect the global power dimensions that have shaped African agricultures.

8 I sketch African cannabis history in the following four sections. The first two of these summarize aspects of my recent book (Duvall, 2019), while the last two review other literature. I stress that I am offering a continent-scale analysis of overarching circumstances, even though circumstances in individual locations may not reflect broader patterns. I briefly discuss exceptions to broad patterns - most notably, current conditions in South Africa - but I am concerned with understanding processes that have similarly affected many locations. In my concluding section, I expand my politicaleconomic interpretation of the historical evidence.

\section{Precolonial Farming}

Cannabis farming began in Africa after the crop arrived from its evolutionary homeland in southern Asia. Various sources of evidence suggest a chronology and geography for the plant's dispersal (Illustration 1). This historical biogeography produced diversity, in terms of plant genetics and human cultures of cannabis use. 
Illustration 1 - Historical dispersal of cannabis in Africa

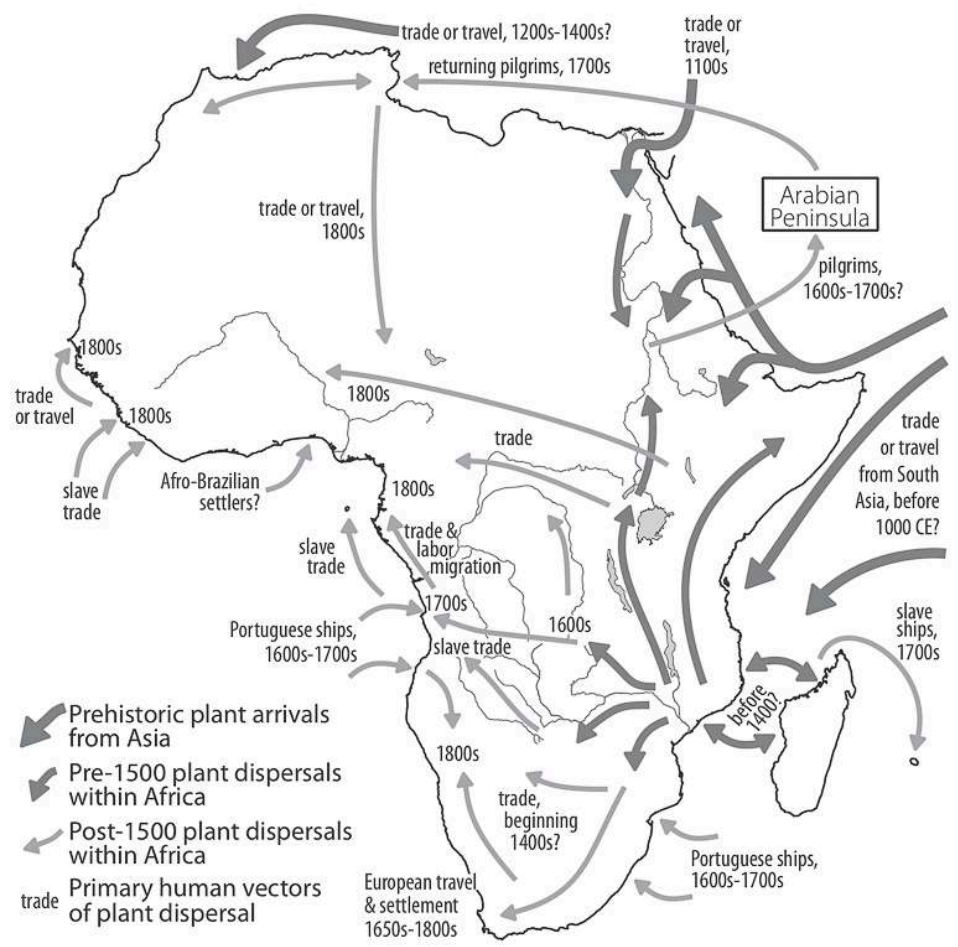

Modified from Duvall (2019).

10 Cannabis came to Africa at least 1,000 years ago, to Madagascar and to the Mediterranean coast. Archaeological evidence is scant, and the continent-wide documentary record principally dates to the nineteenth century. Language geography suggests broad regions in which shared understandings of the plant developed (Illustration 2), although there is insufficient information to characterize historical cannabis cultures for these putative regions. Available evidence can illustrate only a range of historical people-plant interactions (Duvall, 2019, chapters 3-5; Duvall, 2015). 
Illustration 2 - Language geography of words for 'cannabis' in Africa. Each symbol represents one language

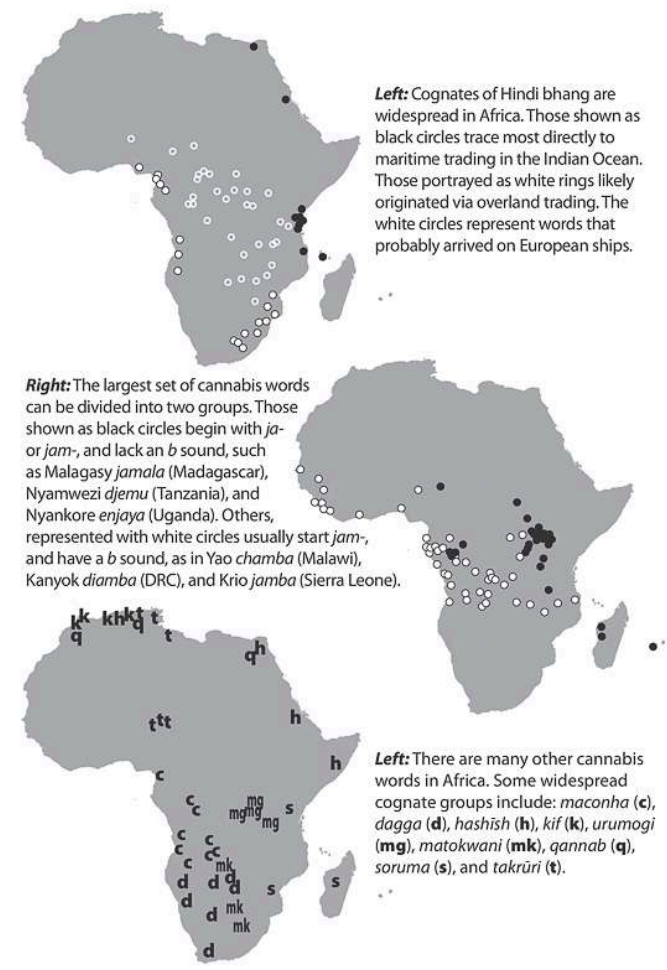

Modified from Duvall (2019).

11 African societies used cannabis in multiple ways, although it was principally valued as a smoked drug. North African farmers planted cannabis for hemp into the early 1900s, but it was always a marginal crop. In sub-Saharan Africa, cannabis fiber was significantly harvested only in Madagascar, where people made hemp fabric. Hemp was not highly valued elsewhere, though cannabis everywhere had multiple uses. In the 1790s in Mozambique, for example, people made cordage from stems and external medicines from leaves, but grew the plant mainly for its smokable inflorescences (Barroso da Silva, 1864 [1799]).

12 Cannabis was a drug crop. In North Africa, writers began describing psychoactive uses in the twelfth century CE (Lozano Cámara, 1996). North African knowledge of psychoactive uses traces to the Levant, where edible cannabis drugs were consumed by 1000 BCE (Russo, 2007). Historical cannabis cultures in Egypt and along the Red Sea remained similar to those of the Levant; cultures were more distinctive in the Maghreb (Morocco, Algeria, and Tunisia). Across North Africa, people consumed inflorescences and hashish (cannabis resin) in both smokable and edible forms. Hashish was historically an import, chiefly from Lebanon, Turkey, and Greece; the earliest regional evidence of hashish production is from 1921, in eastern Algeria (Livet, 1921). Into the 1970s, North African farmers mostly produced herbal material from local cultivars. People mostly planted small plots but sometimes fields of cannabis, notably in northern Morocco where local demand sustained large-scale production in the nineteenth and twentieth centuries.

13 South of the Sahara, historical accounts suggest rich bodies of knowledge about horticulture, ecology, pharmacology, and drug manufacturing (Duvall, 2019, chapters 5 
and 9). Historical farmers grew the crop in a wide range of conditions, and harvested inflorescences. Cannabis gardens were documented in eighteenth-century South Africa and Mozambique, and nineteenth-century Egypt, Angola, Gabon, Sierra Leone, Kenya, Tunisia, and Democratic Republic of Congo (DRC). It was a field crop in Angola in the 1890 s, and Botswana in the 1880s, where it was the only irrigated crop. Yet the plant also grew in isolated patches away from farmland across Central Africa (1850s-1900s), and people harvested feral plants in São Tome (1860s) and South Africa (1890s). The most basic processing technique was to dry the flowers before smoking, but more complex techniques are documented. In South Africa, for instance, people lightly fermented moist herbal material that was dried before use (Bourhill, 1913, p. 14).

Plant genetic diversity developed alongside cannabis cultural diversity. Throughout the continent, people saved seeds from inflorescences harvested for smoking. Thus, agricultural selection favored plants with characteristics that smokers preferred. Travelling smokers helped produce regional populations by scattering seeds between local areas. In southeastern Africa, agricultural selection produced a distinctive cannabis lineage with elevated levels of the appetite-suppressing cannabinoid tetrahydrocannabivarin (THCV) (Hillig and Mahlberg, 2004). Seed savers produced this strain by favoring plants whose biochemistry mitigated hunger; cannabis has been valued as an appetite suppressant in Southern Africa since at least the 1580s (Duvall, 2016). Plant genetics are also broadly understood in the Maghreb. The transMediterranean history of cannabis produced landraces that include genes from psychoactive populations (introduced from the Levant) and non-psychoactive populations (introduced from Europe) (Clarke and Merlin, 2013, p. 330).

Finally, cannabis is a relatively recent arrival in some areas, most prominently West Africa (Duvall, 2019, chapters 4 and 7). The plant drug was not regionally prominent until the 1950s. In locations where the plant is shallowly rooted historically, cannabis cultural diversity and plant genetic diversity appear to be low.

\section{Legal Colonial Cannabis}

16 Africa came under colonial rule mostly during the 1870 s to 1890 s. Cannabis was initially legal under colonial governments but widely outlawed by 1925 , when it became subject to international control under the Geneva Opium Convention (Duvall, 2016; 2019, chapter 9). Even while cannabis was legal, though, colonialists diminished the production capacities of African societies through direct and indirect suppression of the crop.

17 Colonial governance impelled authorities to seek revenue from controlled territories. For centuries, cannabis has been traded in Africa (Duvall, 2019, chapters 4 and 9). Several colonial governments capitalized upon cannabis by taxing preexisting markets (Illustration 3). These were instances of primitive accumulation, though ultimately unsuccessful; they were opportunistic attempts to capture wealth from colonized territory, and not efforts to develop agricultural productivity. The legal, capitalized markets were short-lived, except for Morocco's and Tunisia's cannabis monopolies, which persisted into the 1950s. These monopolies generated significant governmental revenues, whereas trades in Angola, São Tome, Gabon, Mozambique, and South Africa were insufficiently lucrative for the colonial states to forestall enactment of prohibitionist laws. 


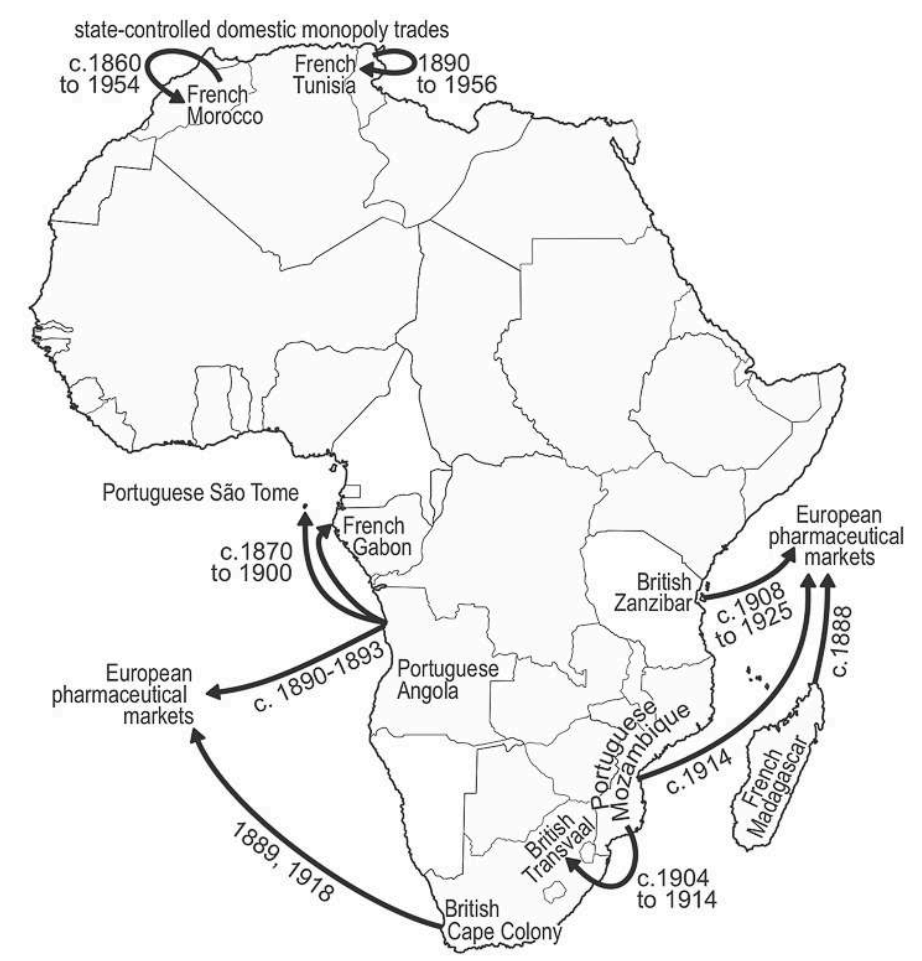

The colonial borders represent conditions in approximately 1900. markets made no efforts to develop cannabis agriculture. Colonial governance was pernicious toward indigenous production capabilities. Several actions directly or indirectly suppressed cannabis prior to prohibition. First, some governments sought to eradicate the crop based on ulterior concerns. French Congo and Ottoman Egypt, for examples, took anti-cannabis measures before prohibiting the plant drug, thinking that drug use diminished labor availability and quality (Commissariat général du Gouvernement, 1907; Kozma, 2011). Second, colonialists viewed cannabis drug use as immoral, which stigmatized farming. This process is well documented in South Africa, where Europeans denounced cannabis gardening by 1818 although it was not outlawed until 1904 (Duvall, 2019, p. 188). Third, colonial governments sought to shift agricultural production toward export crops, including the drugs tobacco, coffee, and tea. In a few instances - in Mozambique, Angola, Madagascar, Zanzibar, and South Africa - European businessmen tried to export cannabis, but they targeted Western pharmaceutical markets and did not build upon indigenous capabilities (Duvall, 2019, p. 207-209). The expansion of cash economies also altered agricultural output. Farmers increasingly needed money to pay taxes, and cannabis, a widely and easily grown crop, was not lucrative.

Altogether, anti-cannabis sentiments pushed cannabis underground before it was legally prohibited (Duvall, 2019, chapters 5 and 9). In French Congo, European travelers documented a transition from open to hidden horticulture between 1880 and 1925. In Sierra Leone, cannabis was widely used and grown in 1850, but by 1900 social elites were unaware of its presence. In South Africa, cannabis growing was increasingly 
concealed after 1850 and nearly invisible by 1900 (Sampson, 1993, p. 6). The plant was shunted toward social-environmental margins. People gardened it in out-of-the-way spots that were not valued for legal crops. Those who chose to use cannabis were increasingly at the fringes of society, such as unemployed workers in South Africa, peasant farmers in Egypt, prostitutes and mendicants in Morocco, and hard laborers in Angola. The early colonial period pre-adapted African cannabis economies to the conditions that formal prohibition produced during the 1900 s.

\section{Illegal Farming}

Most African colonial governments banned cannabis before it was listed in the 1925 Opium Convention (Illustration 4). Additional laws were enacted after this agreement, but drug-law enforcement did not immediately change (Klantschnig, 2014; Akyeampong, 2005; Du Toit, 1980). Arrests continued where authorities were already watching for cannabis; elsewhere, concern grew gradually. Cannabis became salient in many African locations only after World War Two, when returning servicemen and merchant sailors brought it to port cities. Physicians became increasingly concerned about cannabis use and mental illness in African societies (Klantschnig, 2014; Mills, 2003). Anti-cannabis drug-law enforcement intensified globally in the 1960s. The Single Convention on Narcotic Drugs of 1961 established a prohibitionist framework for controlling cannabis, and conservative authorities sought to eradicate the drug that they associated with countercultural movements (Bewley-Taylor et al., 2014). In several African countries, Rastafarianism has been a countercultural target of anti-cannabis campaigns. Independent African countries maintained colonial-era anti-cannabis laws in order to comply with international agreements, and because many elites disapproved of the drug (Carrier and Klantschnig, 2018). In the 1980s, cannabis production increased continent-wide, in correlation with economic crises; production has since grown consistently, although not uniformly between countries (Perez and Laniel, 2004; Carrier and Klantschnig, 2016; Chouvy and Afsahi, 2014; Destrebecq, 2007). Africa has been an active front in the global War on Drugs since the 1990s (Carrier and Klantschnig, 2012; Ellis, 2009), but national governments have shown varying levels of tolerance toward cannabis (Carrier and Klantschnig, 2018).

Illustration 4 - Cannabis-control enacted before the 1925 Opium Convention in Geneva 


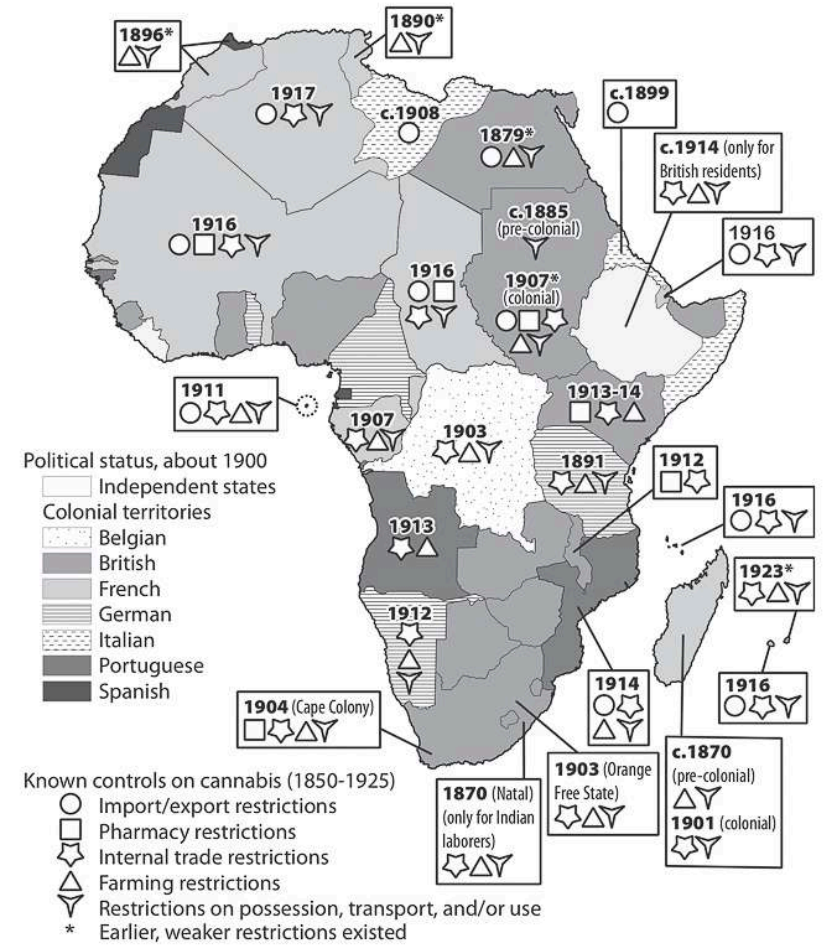

Modified from Duvall (2019). (Kepe, 2003; Bloomer, 2008; Afsahi and Mouna, 2014; Chouvy, 2008; Chouvy and Afsahi, 2014; Suckling, 2016; Laudati, 2014, 2016; Laniel, 2006; Perez and Laniel, 2004; Léonard, 1998; Bernstein, 1999; Allen, 1999; Labrousse and Laniel, 1999; Carrier and Klantschnig, 2016). In general, illegal agriculture has several widespread characteristics. First, it is potentially lucrative. Prohibition places a price premium on cannabis, giving it a form of money-earning potential that legal crops cannot offer. The premium rewards farmers who accept the risks of illegal behavior. If police raid a garden before harvest, an entire season's labor might yield nothing. Farmers are also vulnerable to warmakers, gangs, and others who use violence to capture the value of crops that they did not sow. Cannabis farming has tended to attract poor or socially marginal farmers who are already vulnerable and thus willing to accept risks for the chance to profit. Farmers commonly seek to reduce their risks by hiding the crop in hard-to-access sites and outback areas, although sometimes the crop is grown openly (Chouvy and Afsahi, 2014). The plant can yield satisfactorily in marginal sites, which allows farmers to plant staple crops in better soils while seeking additional income from cannabis sown in otherwise unused land.

Cannabis farming has been profitable, productive, and risky for a century. In Sierra Leone in the 1920s and 1930s, and Nigeria in the 1950s through 1980s, farmers supplied domestic and export markets even though cannabis farming was hardly visible to police (Akyeampong, 2005; Ellis, 2009; Klantschnig, 2014). When the colonial Zimbabwean government promoted cotton in the 1960s and 1970s, many farmers resisted because cannabis was more lucrative (Maravanyika and Maat, 2017). In Côte d'Ivoire, cannabis production boomed after the international cocoa market collapsed in the 1980s (Léonard, 1998). Legal risk has constantly shaped agricultural practices. 
Subsistence farmers in colonial South Sudan had to hide the crop in the 1950s, although they grew it just for household consumption (de Schlippe, 1956). Commercial farmers in colonial DRC reduced their risks by paying non-agricultural foragers ("Pygmies") to tend remote plantations (Turnbull, 1960, p. 37). Illegality has made cannabis a morally checkered crop (Carrier and Klantschnig, 2018). In Kenya in the 1980s, farmers desperate for income sowed cannabis even though earnings from the crop were considered "evil money" (Shipton, 1989). Cannabis has funded warfare in some locations at least since the 1980s. A rebel group in Senegal, for instance, persisted through the 1980s and 1990s because it controlled a cannabis production zone (Faye, 2006).

Even if many poor farmers have earned money from cannabis, the crop has not solved problems of poverty $(\mathrm{jh} / \mathrm{kn} / \mathrm{rz}, 2013)$. Agricultural economies disfavor those who lack capital. Few studies have assessed capital flows in cannabis agriculture. In Ghana in the 1990s, farmers bought seeds and supplies on credit from traffickers, who captured most profits by transporting the crop to market (Labrousse and Laniel, 1999, p. 23). Investments in irrigation, fertilizer, and seedstock helped increase productivity in Morocco since 2000 (Chouvy and Afsahi, 2014). The funds came at least partly from outsiders, including aid intended for legal crops and presumably traffickers; poorer farmers surely failed to invest as much as wealthier ones. The sales and distribution segments of the cannabis economy are more lucrative than farming, and thus often controlled by powerful people. Examples range from the wives of military commanders in eastern DRC (Laudati, 2014), to members of the presidential guard within the Liberia National Police (Daily Observer, 2015). Many cannabis farmers live where drug-law enforcement extends farther into the countryside than other government services. In Zimbabwe in 2014, for instance, farmers in a district without modern healthcare facilities sought unsuccessfully to legalize the cannabis that they grew for traditional medicinal uses (Southern Eye, 2014). Africans are aware of problems that prohibition has produced, but African governments have only recently begun to consider loosening their controls on cannabis.

\section{Twenty-first Century Liberalization}

The current phase of agricultural history is the rapidly unfolding move toward cannabis liberalization. News media have reported steps toward cannabis-policy reform in 22 countries (Illustration 5). Agriculture has been a widespread consideration. Proponents have promoted the crop's untapped value, emphasized opportunities blocked by prohibition, and noted that Global Northern countries are already profiting from liberalization. A politician in eSwatini asserted that the country was losing potential revenue, unlike "First world countries [that] have decriminalised the growing and use of dagga" (Chatora, 2015). A Nigerian presidential candidate stated: "people are making billions out of that particular plant [...]. We should be focusing on it. [Nigeria should be] exporting weed [...] instead of chasing after people who are growing weed" (Toromade, 2018). 
Illustration 5 - Actions taken toward cannabis liberalization. This map is based on published news reports of events since 2010

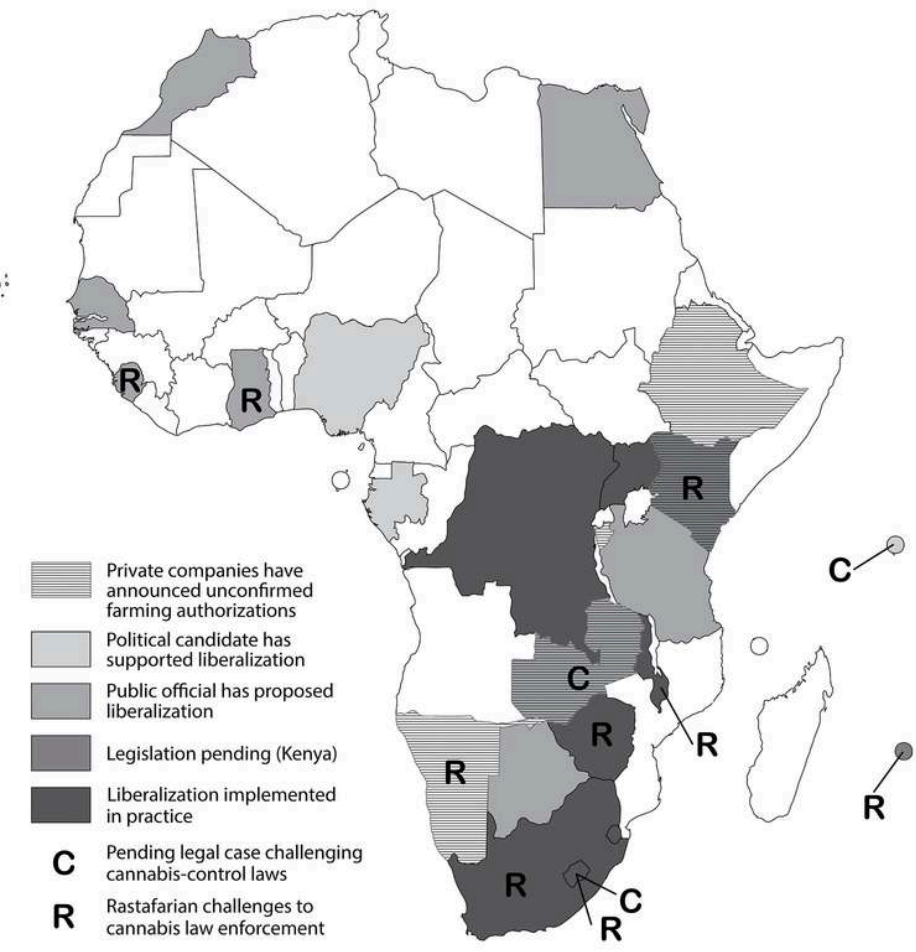

Source: Duvall, unpublished data.

Cannabis liberalization has happened in eight instances ${ }^{1}$. Two of these instances-both in South Africa-did not involve agricultural considerations. The South African parliament authorized medical marijuana ${ }^{2}$ in 2017 in order to benefit ill people, while in 2018 the country's high court decided that adults have the right to garden and use dagga privately (Jansen, 2017; Zondo, 2018). Agricultural development was the explicit motivation for the other six of instances of liberalization. However, these reforms do not obviously benefit African farmers:

Democratic Republic of the Congo: In 2019, a Canadian pharmaceutical company (EXMceuticals) announced that it had, in January 2017, "obtained a license for growing psychotropic and non-psychotropic cannabis on more than 10,000 acres in the DRC. Written into the contract is the potential for practically unlimited expansion of farm land". By August 2018 it had cleared 50 acres, planted 40,000 plants, and harvested 10,000 of them; it has published photos of its operations, and published biographies of two executives of its DRC subsidiary. The DRC government has made no announcements regarding this operation, or how similar licenses might be obtained. EXMceuticals also has announced farming agreements with Malawi and Uganda. The company's shares sell on the Canadian Stock Exchange and the Frankfurt Stock Exchange (EXMceuticals, 2019a, 2019b, 2019c; Canadian Securities Exchange, 2019).

Lesotho: In 2017, the government began licensing cannabis production under existing laws, but did not publish regulations until May 2018. A license to farm is about US $\$ 13,000$ licenses to manufacture, test, or export products cost more. Lesotho's per capita income in 2017 was $\$ 2,925$. The principal company is British-owned Medi Kingdom, but at least three other pharmaceutical companies have begun export 
production. These are foreign-owned (Australia, Canada, South Africa, U.K., U.S.) (Tharoor, 2018; Prohibition Partners, 2019; Motsoeli, 2018; Phakela, 2018; Lamers, 2018; World Bank Group, 2019).

Malawi: In 2016, parliament approved agricultural trials of non-psychoactive cannabis grown for fiber and oilseeds; the trials were partly funded by a British entrepreneur, whose company plans to start commercial production. In October 2018, a CanadianSouth African investor lobbied for a hemp license; soon after, parliament began drafting a bill legalizing non-psychoactive cannabis farming. In February 2019, EXMceuticals announced a deal to grow 2,000 acres of the crop, for psychoactive and non-psychoactive medicinal products; in May, it announced the acquisition of a Malawian agricultural processing firm (Mzungu, 2016; Nyale, 2018; EXMceuticals, 2019b; Malawi Hemp Association, 2019; Kramer, 2018; Khamula, 2018).

eSwatini: In April 2018, a parliamentary committee recommended licensing drug-plant production. A U.S. pharmaceutical company announced a license agreement in January 2019; in March, the business structure of production was published, though licensing was not finalized. Regulations published in March require about US $\$ 71,000$ per license, and licensees must build high-security grow facilities. The country's median income was $\$ 8,640$ in 2017 (bc/jk/he, 2006; World Bank Group, 2019; Profile Solutions, 2019; Chatora, 2015; BM/jn/APA, 2018; GlobeNewswire, 2019).

Uganda: In 2012, Industrial Hemp Uganda (IHU), owned by Ugandans, began advertising hemp fiber products. In 2017 it began growing psychoactive cannabis. In April 2018, EXMceuticals announced a partnership with IHU, which then purchased marijuana seeds from The Netherlands valued at $\$ 42,000$. In July 2018, an Israeli company (Together Pharmaceuticals, traded on the Tel Aviv Stock Exchange) announced that it had been licensed to grow medical marijuana. In January 2019, Together began planting in an IHU-owned facility, and announced its first harvest in June. In October 2018, Together purchased a company that produces and distributes cannabis products in Germany; in April 2019, IHU announced agreements to export to Germany and Canada. IHU, Together, and EXMceuticals seem to have been licensed under existing laws, but no regulations have been published despite at least 12 other applications for licenses (Mugerwa, 2019a, 2019b; URN, 2019; New Vision, 2018; Cannabis Magazine, 2019; EXMceuticals, 2019b; Erez, 2018; Industrial Hemp Uganda, 2018; Bloomberg, 2019).

Zimbabwe: In June 2017, an economy minister accepted an application to grow medical marijuana from a Canadian company. In April 2018, the government published regulations that allowed cannabis growing licenses under existing laws. The application fee was US $\$ 50,000$. The government shortly halted the program, but re-opened it in October upon reducing the fee to US\$10,000. In March 2019, a pharmaceutical company that is based in Zimbabwe but headed by an American announced that it received a license for US\$ 46,000. The per capita GDP in Zimbabwe (2017) was \$ 2,428 (Mawonde, 2018; Chiriga, 2018; Lamers, 2019a; News Day, 2011; Langa, 2018; Ncube, 2017; World Bank Group, 2019; Mashona Central Bureau, 2018).

These cannabis-policy changes have enabled business partnerships made opportunistically with Global Northern companies. In all cases except Uganda, the African governments have reacted solely to lobbying from Northern companies. In Uganda, the government reacted to Ugandan-owned IHU, but only after IHU attracted partnerships with Northern companies. It is impossible to assess if the governments 
have made good deals. DRC has been silent on its agreement, Uganda and Malawi have not published licensing regulations, and regulations were announced in Lesotho and eSwatini only after deals were privately concluded. It is also impossible to evaluate how many Africans have gained income from these ventures. Africans have had noteworthy roles in Uganda (ownership of IHU) and DRC (EXMceuticals has identified two executives of its subsidiary), and in Lesotho (paid license holders for foreigners, although few have succeeded in making such deals: Motsoeli, 2018). The more obvious roles Africans have had are as laborers. The license fees published for Lesotho, eSwatini, and Zimbabwe are unaffordable for most people in those countries. Uganda, DRC, and Malawi have not announced how their citizens-or anyone-might apply for farming licenses.

Further, no reforms have allowed cannabis possession or consumption, and authorities have explicitly discouraged preexisting agriculture. This was a key point when Lesotho's prime minister opened the first licensed farm in December 2018: "For a long time, individuals [...] have been illegally producing marijuana [that is] used for the wrong purposes without any significant benefits for the country and its citizens". His health minister emphasized that licensees would grow "cannabis [that] is not the one that [we] have in the country" (Government of Lesotho, 2018). Some citizens of Lesotho disagree; illegal farming of local varieties provides income to many people (Bloomer, 2008; Tyndale, 2009). "I know it's illegal to plant marijuana," said a single mother in 2018. "[But] My children are in school because of marijuana. When I sell some, I'm then able to pay school fees" (Mkhize, 2018). The cannabis that has become legal in Africa is not the cannabis that has benefitted African farmers.

\section{Canna-colonization}

Beginning in the 1950s, African intellectuals developed the concept of neo-colonialism to understand how political-economic power is wielded internationally after formal colonialism has ended. Ghana's first president Kwame Nkrumah argued that neocolonialism exists when the economic system and political policies of ostensibly independent states are directed from outside. "Neo-colonialist control is exercised through economic or monetary means. [For instance,] Control over government policy [...] may be secured by payments towards the cost of running the State [...]. The result of neo-colonialism is that foreign capital is used for the exploitation rather than for the development of the less developed parts of the world" (Nkrumah, 1965, p. ix). Current instances of cannabis liberalization in Africa epitomize neo-colonialism. The mechanism of payment for favorable cannabis-policies has enabled Global Northern companies to accumulate wealth by dispossessing citizens of African countries of access to the increasingly legal, global cannabis economy.

Neo-colonialism appears in six of the eight instances of cannabis liberalization that have happened in Africa. In these six instances, Global Northern companies sought licenses to produce cannabis under existing laws. Only in Uganda has an African business been clearly involved, although IHU's role may be principally to facilitate foreign direct investment. EXMceuticals owns $70 \%$ of its partnership with $\mathrm{IHU}^{3}$, the same rate that the company reports for subsidiaries in other countries (EXMceuticals, 2019c). No countries have rewritten their drug-control laws. There have been only policy changes, secured by payments - that is, licensing fees - made privately toward 
the costs of governance. The chronologies of policy changes underscore the power of these payments. Lesotho and eSwatini revised cannabis policies only after paid licenses had been granted; EXMceuticals (2019c) currently reports licenses or license applications for countries that have published no changes in in drug-control policies, let alone licensing regulations (DRC, Ethiopia, Kenya, and Uganda).

Reported licensing fees have been tiny relative to the value of the Global Northern cannabis industry, yet far exceed what most citizens of the relevant countries could pay for the opportunity to grow cannabis legally. No drug-policy reforms have allowed casual growing, possession, or use for citizens (except in South Africa). Africans have recognized the global disparity in liberalization reforms. In Zimbabwe in 2014, a local official advocated for people in a rural district: "If countries in North and South America can legalise mbanje, why ban it in [the rural district] where it is part and parcel of their culture?" (Southern Eye, 2014). In 2018, a Rastafarian in Lesotho sued to seek religious rights to dagga, as Lesotho's political elite cheered the first legal exports of cannabis to Canada (Tefo, 2018). The DRC has silently loosened its drug-control policies to favor a Canadian company, while abetting the violence that Congolese farmers experience if they grow the drug crop (Laudati, 2014, 2016). At present, cannabis liberalization has demonstrably benefited few Africans, but has bolstered the prospects of many Global Northern companies and shareholders active in the stock exchanges in Toronto, Tel Aviv, and Frankfurt (Prohibition Partners, 2019). Foreign capital is being used to exploit the continent's resources - land, water, labor, and cannabis - rather than to offer meaningful opportunities for Africans to accumulate wealth.

The plant's agricultural history led to this situation. The long, pre-colonial rise of cannabis farming produced plant diversity that is valuable nowadays. Centuries of agricultural selection produced today's valued local strains and landraces (Duvall, 2016). Africa's cannabis varieties are coveted amongst marijuana seed producers. An American in 2012 stated, "Africa is [...] the mothership for strains that [...] are going to be a huge factor in the future of medical cannabis" (Bluntman, 2012). Indeed, when Uganda's IHU imported marijuana seed from Amsterdam in 2018 (Mugerwa, 2019b), at least two of the strains-Durban Poison and Power Plant-traced to African seedstock (Wikileaf, 2019). Authorized cannabis farming in Africa does not apparently use African seeds, but, at least in Uganda, production has relied upon unrecognized African intellectual property, in the genetic material of landraces used in commercial seed breeding. The bioprospecting that has brought African seeds to the Global North to the benefit of marijuana seed sellers has not returned benefits to African farmers (Duvall, 2016).

38 African territory is now coveted, too. Land grabbing by wealthy countries and companies wishing to grow food and biofuel crops has been described in many academic and news-media sources (cf. Libreti, 2013). Land grabbing is happening in the new, global cannabis economy too, exemplified by EXMceuticals contract claims to more than 130,000 acres of farmland in at least four countries (EXMceuticals, 2019b, 2019c).

In spring 2019, business deals involving African cannabis are being reported in quick succession, often in connection with the Canadian Stock Exchange. Activity has spiked since Canada's legalization event in October 2018, but business has been expanding elsewhere. Israel's Together Pharmaceuticals, for example, has assembled a vertically integrated enterprise linking its Ugandan production to its medical cannabis 
distribution business in Germany (Erez, 2018). Similarly, EXMceuticals (2019c) owns processing and distribution subsidiaries in Canada and Portugal. The powerhouses of cannabis 'development' in Africa are private companies, not former colonial rulers; neocolonial power comes from wealth, not former political relationships.

Pre-colonial agriculture made African cannabis into a valuable crop. Subsequent historical processes have prevented Africans from capturing the crop's value. Colonial governance diminished the continent's production capabilities, in all economic sectors. Although African cannabis farmers have exhibited a century of resilient productivity, colonial governments did not establish resilient or durable institutions to support agricultural development in general. Consequently, African countries are poorly equipped to undertake the type of technocentric production that now characterizes cannabis commercial farming. Thus, knowledge must be imported, rather than identified locally. For instance, Medi Kingdom employs "International experts/ consultants to provide skills transfer to local [...] personnel" in Lesotho (Medi Kingdom, 2019). This approach reflects the modernization theory of development, the idea that poor countries should follow the social-technical-environmental precedents set by wealthy countries rather than alternative pathways (Coetzee et al., 2001; Matunhu, 2011). Modernization theory reinforces ideas about African agricultural backwardness, and facilitates resource grabs in the guise of technical assistance, capacity building, or efficient resource use (Bergius et al., 2018; McMichael, 2013; Zambakari, 2017). Global Northern cannabis companies active in Africa generally present themselves as pursuing socially responsible corporate business. In Lesotho, for instance, the non-profit Medi Kingdom Foundation assists orphans and vulnerable children (Medi Kingdom, 2019; see also Strain Hunters Foundation 2017). Nonetheless, corporate social responsibility activities do not rehabilitate civil and agricultural institutions impoverished by neglect under colonial and post-colonial governments.

Prohibition has weakened the global market positions of Global Southern countries and companies. The international drug control regime has been sustained by voluntary compliance by signatory countries, a volunteerism strengthened by threats of economic and political penalties against violators (Bewley-Taylor, 2012; Tupper and Labate, 2012). African countries have been in weak positions to shape or defy international agreements. Global Northern countries have exercised more autonomy. Since the 1970s, Northern jurisdictions have defected from the dominant regime by liberalizing controls on cannabis and other substances, for various reasons. By defying international agreements, these countries enabled their businesspeople to enter into quasilegal cannabis commerce earlier than people in other parts of the world. The global marijuana seed industry, for instance, is centered in Amsterdam, where controls on cannabis were relaxed beginning in 1976. Marijuana seed producers own the largest collections of African cannabis varieties, which they use to breed high-price, hybrid seeds (Duvall, 2016). Global Northern businesses have arisen from decades of illegally developed expertise in fields from horticulture to medicine; comparable African knowledge has not been similarly valorized. Based on their expertise, Global Northerners have set standards for authorized commercial cannabis farming (Lamers, 2019b), on which Africans must be trained ( $c f$. Medi Kingdom, 2019) Africans are relatively latecomers to liberalized cannabis economies, a disadvantage that adds to those generated earlier in the plant's history. 
$$
\text { of African farmers before those of Global Northern companies. }
$$

The sum of cannabis history is that private companies have accumulated sufficient wealth and power to buy beneficial policies from African governments. Despite the precedents set in DRC, Lesotho, Malawi, eSwatini, Uganda, and Zimbabwe, other reform pathways are possible. Examples come from Kenya and Morocco, where no reforms have happened, and South Africa, which has enacted reforms. Compared with its neighbors, South Africa is exceptional in many aspects of its political-economic history. Its cannabis liberalization reforms - legalization of medical marijuana in 2017 and of adult-use dagga in 2018 (Jansen, 2017; Zondo, 2018) - are exceptional because they trace to South African citizens who sought legal changes. These reforms did not happen because businesses lobbied for access to land, labor, water, cannabis, or other resources. The 2017 medical marijuana reform narrowly enabled cannabis commerce, but the 2018 court decision did not establish rights to sell dagga. Few South Africans can legally earn money from cannabis, though all adults are now allowed to cultivate the crop for themselves ${ }^{5}$.

Additionally, potential reforms discussed by politicians in Kenya and Morocco are directed toward the interests of citizens. of course, these reform ideas may simply be self-serving political proclamations. Nonetheless, in both countries, reform ideas have acknowledged political ecologies that have disadvantaged citizens. In Morocco in 2016, a politician portrayed kif farming as an outcome of political-economic marginalization tracing back to the colonial period: "these modest farmers [...] are victims of the difficult conditions in their region [...]. It is time for the [Rif Mountains] region and its people to benefit from their rights to development" (Jaouhari, 2016; see also Schemm and Bellaoualli, 2014; Lamlili, 2018). A bill forming in Kenya's parliament seems likely to interest many Kenyans: it would decriminalize possession and consumption, expunge records of past arrests, and allow farming by registered growers (Omul, 2018). The bill arose from post-colonial thought, as expressed by a Kenyan scholar testifying before parliament: "it is medicine [and] it was [...] until the colonialists came and illegalized it. We are reinstating the freedom. If we see value in it that they don't see, it doesn't mean we have to go their way" (Muchangi, 2017).

Many African countries are contemplating liberalization. If drug-policy reforms are built upon awareness of the history of cannabis in Africa, they will place the interests

\section{BIBLIOGRAPHY}

Afsahi, K., Mouna K., 2014. Cannabis dans le Rif central (Maroc). Construction d'un espace de déviance. Espaces Temps [Online]. www.espacestemps.net/en/articles/cannabis-dans-le-rifcentral-maroc-2/ (accessed on 12 August 2018)

Aggarwal S. K., 2013. Tis in our nature: taking the human-cannabis relationship seriously in health science and public policy. Frontiers in psychiatry, vol. $4, \mathrm{n}^{\circ} 6$. 
Aggarwal S. K., Carter G. T., Zumbrunnen C., Morrill R., Sullivan M., Mayer J. D. 2012.

Psychoactive substances and the political ecology of mental distress. Harm Reduction Journal vol. 9, $\mathrm{n}^{\circ} 1, \mathrm{p} .4$.

Akyeampong E., 2005. Diaspora and drug trafficking in West Africa: A case study of Ghana. African Affairs, vol. 104, n 416, p. 429-447 [Online]. https://doi.org/10.1093/afraf/adi034

Allen C., 1999. Africa and the drugs trade. Review of African Political Economy, vol. 79, p. 5-11.

Barroso da Silva F.M., 1864 [1799]. Descripção de algumas drogas e medicamentos da India, feita em 1799 pelos Facultativos de Goa. Archivo de Pharmacia e Sciencias Accessorias da India Portugueza, vol. $1, \mathrm{n}^{\circ} 12$, p. 185-191.

bc/jk/he, 2006. Illegal cannabis could become legal 'Swazi Gold'. IRIN News [Online], 30 October. http://www.irinnews.org/report/61441/swaziland-illegal-cannabis-could-become-legal-swazigold (consulted on 28 February 2019)

Bergius M., Benjaminsen T. A., Widgren M., 2018. Green economy, Scandinavian investments and agricultural modernization in Tanzania. The Journal of Peasant Studies, vol. 45, nº 4, p. 825-852.

Bernstein H., 1999. Ghana's drug economy: some preliminary data. Review of African Political Economy, vol. 26, n 79, p. 13-32.

Bewley-Taylor D., Jelsma M., 2012. Regime change: Re-visiting the 1961 Single Convention on Narcotic Drugs. International Journal of Drug Policy, vol. 23, $n^{\circ}$ 1, p. 72-81.

Bewley-Taylor, D., Blickman T., Jelsma M., 2014. The Rise and Decline of Cannabis Prohibition. Amsterdam, Transnational Institute.

Bloomberg, 2019. TGTR:IT Together Pharma Ltd [Online]. Bloomberg L.P. [New York]. https:// www.bloomberg.com/quote/TGTR:IT (consulted on 22 March 2019).

Bloomer J., 2008. Using a political ecology framework to examine extra-legal livelihood strategies: a Lesotho-based case study of cultivation of and trade in cannabis. Journal of Political Ecology, vol. 16, p. 49-69.

Bluntman B., 2012. The Future of Sativas: African Strains. Marijuana.com [Orange County, California], 28 March [Online]. https://www.marijuana.com/news/2012/03/the-future-ofsativas-african-strains (consulted on 30 April 2018).

$\mathrm{BM} / \mathrm{jn} / \mathrm{APA}, 2018$. More research needed before Swaziland legalises marijuana - WHO. Agence de Presse Africaine, 12 April [Online]. http://apanews.net/index.php/en/news/more-researchneeded-before-swaziland-legalises-marijuana-who (consulted on 28 February 2019)

Bourhill C.J.G., 1913. The smoking of dagga (Indian hemp) among the native races of South Africa and the resultant evils. M.D. dissertation, University of Edinburgh.

Bozonnet C., 2017. Une grande partie de l'argent du haschich ne profite pas à l'économie marocaine. Le Monde, 30 March [Online]. https://www.lemonde.fr/afrique/article/2017/03/30/ une-grande-partie-de-l-argent-du-haschich-ne-profite-pas-a-l-economiemarocaine_5103423_3212.html

Buxton J., 2006. The Political Economy of Narcotics: Production, Consumption and Global Markets. London, Zed Books.

Buxton J., 2015. Drugs and Development: The Great Disconnect. Policy Report 2. Singleton Park, UK, Global Drug Policy Observatory. 
Canadian Securities Exchange, 2019. EXMceuticals, Inc. CNSX Markets, Toronto [Online]. https:// thecse.com/en/listings/life-sciences/exmceuticals-inc (consulted on 22 March 2019)

Cannabis Magazine, 2019. An Israeli company began growing cannabis in Uganda, Cannabis Magazine [Tel Aviv?], 27 January [Online]. https://www.xn--4dbcyzi5a.com/en/2019/01/AnIsraeli-company-began-growing-cannabis-in-Uganda/ (consulted on 28 February 2019)

Carrier N., Klantschnig G., 2012. Africa and the War on Drugs. London, Zed Books.

Carrier N., Klantschnig G., 2016. Illicit livelihoods: drug crops and development in Africa. Review of African Political Economy, vol. 43, n 148, p. 174-189.

Carrier N., Klantschnig G., 2018. Quasilegality: khat, cannabis and Africa's drug laws. Third World Quarterly, vol. 39, n 2, p. 350-365.

Chatora A., 2015. Swaziland should legalise marijuana to boost economy - minister. ThisIsAfrica.me [United States?], 10 December [Online]. https://thisisafrica.me/swazilandminister-says-government-should-legalise-marijuana-to-boost-economy/ (consulted on 28 February 2019)

Chiriga E., 2018. Govt suspends mbanje licensing. Daily News Live, 20 May [Online]. https:// www.dailynews.co.zw/articles/2018/05/20/govt-suspends-mbanje-licensing (consulted on 28 February 2019)

Chouvy P.-A., 2008. Production de cannabis et de haschich au Maroc: Contexte et enjeux. L'Espace Politique [En ligne], vol. 4, $\mathrm{n}^{\circ} 1$. http://journals.openedition.org/espacepolitique/59 - DOI : 10.4000/espacepolitique.59

Chouv, P.-A., Afsahi K., 2014. Hashish revival in Morocco. International Journal of Drug Policy, vol. $25, n^{\circ} 3$, p. 416-423.

Clarke R.C., Merlin M.D., 2013. Cannabis: Evolution and Ethnobotany. Berkeley, CA, University of California Press.

Coetzee J.K., Graaff J., Heindricks F., Wood G., 2001. Development: Theory, Policy, and Practice. Cape Town, Oxford University Press.

Commissariat Général du Gouvernement, 1907. Circulaire au sujet des mesures à prendre contre l'usage et la diffusion du chanvre. Bulletin Officiel Administratif des Possessions du Congo Français et Dépendances et du Moyen-Congo, March, p. 161-162.

Daily Observer [Monrovia], 2015. Senior Police Officer Charged for Smuggling L\$318,000 Marijuana, Daily Observer, 7 January [Online]. https://www.liberianobserver.com/ news/senior-police-officer-charged-for-smuggling-l318000-marijuana/ (consulted on 28 February 2019)

de Schlippe P., 1956. Shifting cultivation in Africa: the Zande system of agriculture. London, Routledge and Kegan Paul.

Destrebecq D., 2007. Cannabis in Africa: An Overview. New York, United Nations Office on Drugs and Crime.

Duvall C.S., 2015. Cannabis. London, Reaktion Books.

Duvall C.S., 2016. Drug laws, bioprospecting, and the agricultural heritage of Cannabis in Africa. Space \& Polity, vol. 20, $\mathrm{n}^{\circ} 1$, p. 10-25.

Duvall C.S., 2019. The African Roots of Marijuana. Durham, NC, Duke University Press.

Ellis S., 2009. West Africa's international drug trade. African Affairs, vol. 108, n 431, p. 171-196. 
Erez G., 2018. What Is an Israeli Cannabis Company Doing in Uganda? The Answer Is Hazy. Haaretz [Tel Aviv], 11 October [Online]. https://www.haaretz.com/israel-news/business/what-is-anisraeli-cannabis-company-doing-in-uganda-the-answer-is-hazy-1.6548072 (consulted on 28 February 2019)

Erin Resources, 2015. MGC Secures Option for Cannabis Growing License in Namibia. Australian Securities Exchange [Sydney], 22 July [Online]. https://www.asx.com.au/asxpdf/20150722/pdf/ 42zys01cd99bdm.pdf (consulted on 28 February 2019).

EXMceuticals, 2019a. Status [Reports]. EXMceuticals [Vancouver], 2018-2019 [Online]. https:// exmceuticals.com/operations/status (consulted on 28 February 2019)

EXMceuticals, 2019b. News Releases. EXMceuticals [Vancouver], 2018-2019 [Online]. https:// exmceuticals.com/news-releases (consulted on 21 June 2019)

EXMceuticals, 2019c. Introduction to EXMceuticals v3.0. EXMceuticals [Vancouver], November [Online]. https://exmceuticals.com/media/documents/ EXMceuticals_Company_Introduction_v3.1.pdf (consulted on 21 June 2019)

Fairbairn M., 2013. Indirect dispossession: Domestic power imbalances and foreign access to land in Mozambique. Development and Change. vol. 44, $\mathrm{n}^{\circ}$ 2, p. 335-356.

Faye W., 2006. The Casamance Separatism: From Independence Claim to Resource Logic. M.S. Thesis, Naval Postgraduate School, Monterey, California.

Getachew S., 2019. Cannabis FDI: Sending shockwaves in Ethiopia. The Reporter [Addis Ababa], 13 April [Online]. https://www.thereporterethiopia.com/article/cannabis-fdi-sendingshockwaves-ethiopia (consulted on 21 June 2019)

GlobeNewswire, 2019. Stem Holdings, Inc. Enters the Global Cannabis \& Industrial Hemp Market with acquisition of South African Ventures, Inc., Nasdaq.com [New York], 25 March [Online]. https://www.nasdaq.com/press-release/stem-holdings-inc-enters-the-global-cannabis-industrial-hemp-market-with-acquisition-of-south-20190325-00355 (consulted on 21 June 2019)

Government of Lesotho, 2018. PM launches cannabis cultivator. Government of Lesotho News [Maseru], 11 December [Online]. https://www.gov.ls/pm-launches-cannabis-cultivator/ (consulted on 28 February 2019)

Haag D., 2011. Mechanisms of Neo-colonialism: Current French and British influence in Cameroon and Ghana. Working Paper 2011/6. Barcelona, International Catalan Institute for Peace.

Hagmann, T., Reyntjens F., 2016. Aid and Authoritarianism in Africa: Development without Democracy. London, Zed Books.

Harvey D., 2004. The 'new' imperialism: Accumulation by dispossession. Socialist Register, vol. 40, p. 63-87.

Ince O. U., 2014. Primitive accumulation, new enclosures, and global land grabs: A theoretical intervention. Rural Sociology, vol. 79, nº 1, p. 104-131.

Industrial Hemp Uganda, 2018. Home [Online]. Industrial Hemp Uganda, Ltd. [Kampala]. http:// www.hempuganda.com/ (consulted on 28 February 2019)

Jansen Z., 2017. Medical marijuana bill rejected, but... Sunday Independent Online [Cape Town], 26 November [Online]. https://www.iol.co.za/sundayindependent/analysis/medical-marijuanabill-rejected-but-12157890 (consulted on 28 February 2019) 
Jaouhari M., 2016. Le PAM promet l'amnistie Générale pour les cultivateurs de Kif. Medias24.com [Casablanca], 15 August [Online]. www.medias24.com/MAROC/NATION/POLITIQUE/166295-LePAM-promet-l-amnistie-generale-pour-les-cultivateurs-de-Kif.html

$\mathrm{jh} / \mathrm{kn} / \mathrm{rz}, 2013$. Growing marijuana to make ends meet in Swaziland. IRIN News [Geneva], 6 September [Online]. http://www.thenewhumanitarian.org/news/2013/09/06 (consulted on 28 February 2019)

Johnson N., 2017. Grass roots: a history of cannabis in the American West. Corvallis, Oregon State University Press.

Kalunta-Crumpton A. (ed.), 2015. Pan-African Issues in Drugs and Drug Control An International Perspective. New York, Routledge.

Kepe T., 2003. Cannabis sativa and rural livelihoods in South Africa: politics of cultivation, trade and value in Pondoland. Development Southern Africa, vol. 20, n 5, p. 605-615.

Khamula O., 2018. Cannabis Investors Woo Malawi On Industrial Hemp. Nyasa Times [Lilongwe], 30 October [Online]. https://www.nyasatimes.com/cannabis-investors-woo-malawi-onindustrial-hemp/ (consulted on 28 February 2019)

Klantschnig G., 2014. Histories of cannabis use and control in Nigeria, 1927-1967. In Klantschnig G., Carrier N., Ambler C. (eds.), Drugs in Africa: Histories and Ethnographies of Use. Gordonsville, NY, Palgrave Macmillan, p. 69-88.

Kozma L., 2011. Cannabis Prohibition in Egypt, 1880-1939: From Local Ban to League of Nations Diplomacy. Middle Eastern Studies, vol. 47, n 3, p. 443-460.

Kramer B., 2018. The Entrepreneurial Spirit - Invegrow. Malawi Hemp Association, 29 May [Online]. https://www.malawihemp.org/article/invegrow-the-entrepreneurial-spirit (consulted on 28 February 2019)

Labrousse A., Laniel L., 1999. The Drug Nexus in Africa. Vienna, United Nations Office for Drug Control and Crime Prevention.

Lamers M., 2018. In a first, Africa exports medical marijuana to Canada. Marijuana Business Daily [Denver], 26 March [Online]. https://mjbizdaily.com/first-africa-exports-medical-marijuanacanada/ (consulted on 28 February 2019)

Lamers M., 2019a. Zimbabwe approves first license for private cannabis company. Marijuana Business Daily [Denver], 13 March [Online]. https://mjbizdaily.com/zimbabwe-issues-first-licenseprivate-cannabis-company/ (consulted on 15 March 2019)

Lamers M., 2019b. Going Global? Join the GMP Parade. Marijuana Business Magazine [Denver], March [Online]. https://mjbizmagazine.com/going-global-join-the-gmp-parade/ (consulted on 21 June 2019)

Lamlili N., 2018. La legislation du cannabis en débat au Maroc. Jeune Afrique, 18 April [Online]. www.jeuneafrique.com/mag/549110/societe/la-legalisation-du-cannabis-en-debat-au-maroc/

Langa V., 2018. Govt amends mbanje-growing regulations. News Day [Harare], 2 October [Online]. https://www.newsday.co.zw/2018/10/govt-amends-mbanje-growing-regulations/ (consulted on 28 February 2019)

Langan M., 2018. Neo-colonialism and the Poverty of 'Development' in Africa. Cham, Switzerland, Palgrave Macmillan.

Laniel L., 2006. Producing cannabis in Africa south of the Sahara: A review of OGD findings in the 1990s. Oxford, UK: International Workshop on Drugs and Alcohol in Africa: Production, Distribution, 
Consumption, and Control [Online]. http://laniel.free.fr/INDEXES/PapersIndex/ CANNABIS_AFRICA_OXFORD/Cannabis_in_Africa_Oxford.htm (consulted on 30 June 2018)

Laudati A. A., 2014. Out of the shadows: Negotiations and networks in the cannabis trade in eastern Democratic Republic of Congo. In Klantschnig G., Carrier N., Ambler C. (eds.), Drugs in Africa: Histories and Ethnographies of Use. Gordonsville, NY, Palgrave Macmillan, p. 161-181.

Laudati A. A., 2016. Securing (in)security: relinking violence and the trade in cannabis sativa in eastern Democratic Republic of Congo. Review of African Political Economy, vol. 43, n 148, p. 190-205.

Léonard É., 1998. Crise des économies de plantation et trafic de drogues en Afrique de l'Ouest : les cas ivoirien et ghanéen. Autrepart, n 8, p. 79-102.

Liberti S., 2013. Land grabbing: Journeys in the new colonialism. London, Verso Books.

Livet L., 1921. Les fumeurs de Kif. Bulletin de la Société clinique de médecine mentale, n 9,17 January, p. $40-45$.

Lozano Cámara I., 1996. Terminología científica árabe del cáñamo. In Álvarez de Morales C. (ed.), Ciencias naturaleza en al-Andalus (Textos y estudios IV). Granada, Spain, CSIC, p. 147-164.

Malawi Hemp Association, 2019. Home [Online], Malawi Hemp Association [Lilongwe]. https:// malawihemp.org/ (consulted on 28 February 2019)

Maravanyika, S., Maat H., 2017. Resorting to Illegality: The Illicit Shangwe Cannabis Trade as an Anti-cotton Response to Agrarian Policy in Colonial Zimbabwe, c. 1962-1979. In Munyaradzi M. (ed.), The Political Economy of Poverty, Vulnerability and Disaster Risk Management. Bamenda, Cameroon, Langaa Research and Publishing Common Initiative Group, p. 93-122.

Mashona Central Bureau, 2018. \$10m for cannabis production facility. The Herald [Harare], 18 September [Online]. https://www.herald.co.zw/10m-for-cannabis-production-facility/ (consulted on 28 February 2019)

Matunhu J., 2011. A critique of modernization and dependency theories in Africa. African Journal of History and Culture, vol. 3, n 5, p. 65-72.

Mawonde A., 2018. Govt legalises mbanje farming. The Herald [Harare], 28 April [Online]. https:// www.herald.co.zw/govt-legalises-mbanje-farming/ (consulted on 28 February 2019)

McMichael P., 2013. Land grabbing as security mercantilism in international relations. Globalizations, vol. 10, $\mathrm{n}^{\circ} 1$, p. 47-64.

Medi Kingdom, 2019. Home [Online], Medi Kingdom Ltd. [Maseru]. https:// www.medikingdom.com/ (consulted on 21 June 2019)

Mills J.H., 2003. Cannabis Britannica: Empire, trade, and prohibition, 1800-1928. Oxford, Oxford University Press.

Mkhize V., 2018. Marijuana, mountains and money: How Lesotho is cashing in. BBC News, 28 November [Online]. https://www.bbc.com/news/world-africa-46288374 (consulted on 28 February 2019)

Motsoeli N., 2018. Locals in danger of losing out on lucrative cannabis industry. Lesotho Times, 12 December [Online]. http://lestimes.com/locals-in-danger-of-losing-out-on-lucrativecannabis-industry/ (consulted on 28 February 2019)

Muchangi J., 2017. Legalise bhang to free Kenyans from 50 years of colonial oppression - Ogot. 10 April [Online]. https://www.the-star.co.ke/news/2017/04/10/legalise-bhang-to-free-kenyansfrom-50-years-of-colonial-oppression_c1541555 (consulted on 28 February 2019) 
Mugerwa Y., 2019a. Government seals Shs600b deal to export marijuana. Daily Monitor [Kampala], 23 April [Online]. https://mobile.monitor.co.ug/News/Government-Shs600b-deal-exportmarijuana-Kasese-Museveni-/2466686-5083246-format-xhtml-iy8ucu/index.html (consulted on 21 June 2019)

Mugerwa Y., 2019b. Uganda pays Shs1b for marijuana seeds, soils. Daily Monitor [Kampala], 17 May [Online]. https://www.monitor.co.ug/News/National/Uganda-pays-Shs1b-for-marijuana-seedssoils/688334-5119032-robupgz/index.html (consulted on 21 June 2019)

Musoni E., 2010. Gov't seeks to legalize marijuana for medical use. The New Times [Kigali], 10 June [Online]. https://www.newtimes.co.rw/section/read/20695 (consulted on 28 February 2019)

Mzungu W., 2016. House adopts motion on chamba cultivation. The Nation [Blantyre], 17 June [Online]. https://mwnation.com/house-adopts-motion-on-chamba-cultivation/ (consulted on 28 February 2019)

Ncube L., 2017. Zim to legalise mbanje. The Sunday News, 7 July [Online]. https:// www.sundaynews.co.zw/zim-to-legalise-mbanje-govt-considers-drug-use-for-medical-purposes/ (consulted on 28 February 2019)

New Vision, 2018. Israeli Investors To Grow Marijuana in Uganda. New Vision [Kampala], 24 July [Online]. https://www.newvision.co.ug/new_vision/news/1481976/israeli-investors-growmarijuana-uganda (consulted on 28 February 2019)

News Day, 2011. Legalise marijuana: MP. News Day [Harare], 18 February [Online]. https:// www.newsday.co.zw/2011/02/2011-02-18-legalise-marijuana-mp/ (consulted on 28 February 2019)

News24 Correspondent, 2017. Zim mulls legalising production of cannabis to lure investment. News24 [Johannesburg], 10 July [Online]. https://www.news24.com/Africa/Zimbabwe/zim-mullslegalising-production-of-cannabis-to-lure-investment-20170710 (consulted on 28 February 2019)

Nkrumah K., 1965. Neo-Colonialism: The Last Stage of Imperialism. London, Nelson.

Ntambara P., 2010. Sezibera clarifies on narcotics bill. The New Times [Kigali], 12 June [Online]. https://www.newtimes.co.rw/section/read/20802 (consulted on 28 February 2019)

Nyale E., 2018. House allows industrial hemp bill drafting. The Nation [Blantyre], 17 December [Online]. https://mwnation.com/house-allows-industrial-hemp-bill-drafting/ (consulted on 28 February 2019)

Omul C., 2018. Kibra MP plants Bill on legalising bhang use, growth. Daily Nation, 21 September [Online]. https://www.nation.co.ke/news/MP-in-push-for-Kenya-to-legalise-bhang/ 1056-4771060-jjxe5lz/index.html (consulted on 28 February 2019)

Perez P., Laniel L., 2004. Croissance et... croissance de l'économie du cannabis en Afrique subsaharienne. Hérodote, vol. 112, n 1, p. 122-138.

Phakela M., 2018. 500k for medical marijuana licence. Lesotho Times, 2 June [Online]. http:// lestimes.com/500k-for-medical-marijuana-licence/ (consulted on 28 February 2019)

Pontes Fraga P. C., Silva Iulianelli J. A., 2011. Plantios ilícitos de 'cannabis' no Brasil: Desigualdades, alternativa de renda e cultivo de compensação. DILEMAS: Revista de Estudos de Confl ito e Controle Social, vol. $4, \mathrm{n}^{\circ} 1, \mathrm{p} .11-39$.

Profile Solutions. 2019. PSIQ Secures $\$ 2,500,000$ to Become the Only Licensed Growing Farm and Processing Plant for Medical Cannabis \& Hemp in eSwatini for a Minimum of 10 Years. Globe Newswire, 16 January [Online]. https://globenewswire.com/news-release/2019/01/16/1696716/0/ 
en/PSIQ-Secures-2-500-000-to-Become-the-Only-Licensed-Growing-Farm-and-Processing-Plantfor-Medical-Cannabis-Hemp-in-eSwatini-for-a-Minimum-of-10-Years.html (consulted on 28 February 2019)

Prohibition Partners, 2019. The African Cannabis Report. Prohibition Partners, London [Online]. https://prohibitionpartners.com/ (consulted on 22 March 2019)

Rhodes T., 2009. Risk environments and drug harms: a social science for harm reduction approach. International Journal of Drug Policy, vol. 20, n 3, p. 193-201.

Robbins P., 2011 (2 ed.). Political ecology. Malden, USA, Blackwell.

Robertson B., Pinstrup-Andersen P., 2010. Global land acquisition: neo-colonialism or development opportunity? Food Security, vol. 2, n 3, p. 271-283.

Rodney W., 2018 [1972]. How Europe Underdeveloped Africa. Brooklyn, NY, Verso.

Russo E.B., 2007. History of cannabis and its preparations in saga, science, and sobriquet.

Chemistry and Biodiversity, $\mathrm{n}^{\circ}$ 4, p. 1614-1648.

Sampson C.G., 1993. 'Zeer grote liefhebbers van tobak': Nicotine and cannabis dependency of the Seacow River Bushmen. The Digging Stick, vol. 10, n 1, p. 2-6.

Schemm P., Bellaoualli S., 2014. Morocco, top hash provider, mulls legislation to break marijuana taboo and legalize growing. The Globe and Mail, 7 October [Online]. https://

www.theglobeandmail.com/news/world/morocco-top-hash-provider-mulls-legislation-to-breakmarijuana-taboo-and-legalize-growing/article20959360/?page=all (consulted on 28 February 2019)

Shipton P., 1989. Bitter Money: Cultural Economy and Some African Meanings of Forbidden Commodities. Washington, DC, American Anthropological Association.

Smith N., 1997. The Satanic Geographies of Globalization: Uneven Development in the 1990s. Public Culture, vol. 10, n 1, p. 169-189.

Southern Eye, 2014. Binga villagers want freedom to use mbanje. Southern Eye [Bulawayo?], 30 March [Online]. https://www.southerneye.co.zw/2014/03/30/binga-villagers-want-freedomuse-mbanje/ (consulted on 28 February 2019)

Strain Hunters Foundation, 2017. Home [Online], Strain Hunters Foundation [Amsterdam]. https://www.strainhuntersfoundation.com/ (consulted on 21 June 2019)

Suckling C.A., 2016. Chain work: the cultivation of hierarchy in Sierra Leone's cannabis economy. Review of African Political Economy, vol. 43, n 148, p. 206-226.

Taylor I., 2016. Dependency redux: why Africa is not rising. Review of African Political Economy, vol. 43, n 147, p. 8-25.

Taylor I., 2019. France à fric: the CFA zone in Africa and neocolonialism. Third World Quarterly [Online], p. 1064-1088. https://doi.org/10.1080/01436597.2019.1585183

Tefo T., 2018. Concourt hears landmark marijuana case. Sunday Express [Maseru], 13 March [Online]. https://sundayexpress.co.ls/concourt-hears-landmark-marijuana-case/ (consulted on 28 February 2019)

Tharoor A., 2018. US Corp Cashes in as Lesotho Becomes the First African Country to Legalise Cannabis. TalkingDrugs.org [London], 7 February [Online]. https://www.talkingdrugs.org/lesothocannabis-legalisation-restricted (consulted on 28 February 2019) 
Toromade S., 2018. Aspirant says he'll export marijuana as Nigeria's President. Pulse NG, 6 September [Online]. https://www.pulse.ng/news/politics/sowore-aspirant-says-hell-exportmarijuana-as-nigerias-president/m68lwyd (consulted on 28 February 2019)

Tupper K., Labate B., 2012. Plants, psychoactive substances and the International Narcotics Control Board: The control of nature and the nature of control. Human Rights and Drugs, vol. 2, $\mathrm{n}^{\circ} 1$.

Turnbull C. M., 1960. Field Work Among the Bambuti Pygmies, Belgian Congo: A Preliminary Report. Man, $\mathrm{n}^{\circ}$ 60, p. 36-40.

Tyndale R., 2009. Growing cannabis in Lesotho: a matter of survival. Dialogues, Proposals, and Stories for Global Citizenship [Lausanne, Switzerland], 1 January [Online]. http://base.d-p-h.info/ en/fiches/dph/fiche-dph-7988.html (consulted on 28 February 2019)

United Nations Office on Drugs and Crime, 2018. World Drug Report 2018. New York, United Nations.

URN, 2019. Israeli firm reports first cannabis harvest from Uganda. The Observer [Kampala], 19 June [Online]. https://observer.ug/news/headlines/61096-israeli-firm-reports-first-cannabisharvest-from-uganda (consulted on 21 June 2019)

Wikileaf, 2019. All Cannabis Strains [database]. Wikileaf.com. https://www.wikileaf.com/strains/ (consulted on 21 June 2019)

World Bank Group, 2019. World Bank Open Data [Online]. The World Bank. https:// data.worldbank.org/ (consulted on 16 March 2019)

Zambakari C., 2017. Land Grab and Institutional Legacy of Colonialism: The Case of Sudan. Consilience, $\mathrm{n}^{\circ} 18, \mathrm{p} .193-204$.

Zondo A.C.J., 2018. Minister of Justice and Constitutional Development and Others v Prince [and Others] ZACC 30 [court decision]. Constitutional Court of South Africa, Case CCT 108/17, 18 September [Online]. http://www.saflii.org/za/cases/ZACC/2018/30.html (consulted on 28 February 2019)

Zurayk R., 2013. Should farmers just say no? Journal of Agriculture, Food Systems, and Community Development, vol. $4, \mathrm{n}^{\circ} 1$, p. 11-14.

\section{NOTES}

1. Additionally, EXMceuticals, a Canadian company, has announced negotiations to grow in Burundi, Zambia, Kenya, and Ethiopia (EXMceuticals 2019a). The Ethiopia case seems most substantial; the company has published the name of the CEO of a claimed Ethiopian subsidiary (EXMceuticals, 2019c). However, the Ethiopian Minister of Health denied that any cannabis licenses have been issued (Getachew, 2019), and no other reports have confirmed EXMceutical's announcements. Similarly, in 2015, an Australian company announced that it had received a license to grow cannabis in Namibia (Erin Resources, 2015), but no other sources confirm this relationship. Finally, in 2010 a Rwandan newspaper reported that the Minister of Health supported medical marijuana legalization. The minister subsequently denied this, and expressed support for the criminalization of drug use (Musoni, 2010; Ntambara, 2010).

2. In popular discourse, "medical marijuana" refers to psychoactive and non-psychoactive, therapeutic applications of cannabis. I use this term in contexts where such applications are the stated purpose for cannabis liberalization or production. 
3. The terms of IHU's partnership with Israel's Together Pharmaceuticals are not known.

4. IHU probably bought from Dutch Passion Seed Company, which offers the strains listed in Ugandan customs records reported by Mugerwa (2019b), including the trademarked strain "CBD Auto Charlotte's Angel” (see Dutch Passion's online catalog: https://www.dutch-passion.com/en/ cannabis-seeds/).

5. Parliament has until September 2020 to enact legislation that complies with the 2018 decision, and it will likely also consider whether adult-use commerce might be opened.

\section{ABSTRACTS}

This article outlines four historical phases of cannabis cultivation in Africa. First, during the plant's initial dispersal across the continent, people developed diverse cultures of cannabis farming and use. Second, several formal markets for cannabis developed under colonial regimes, although colonialists more widely suppressed the crop. Third, twentieth-century drug laws changed the economics of production, causing cannabis farming to become particularly attractive to resource-poor farmers. Finally, several countries have recently legalized cannabis cultivation in specific contexts. Altogether, the crop's agricultural history has produced relationships that enable Global Northerners to extract more value from African resources than African farmers can extract.

\section{INDEX}

Keywords: economic development, capitalism, neocolonialism, foreign direct investment

\section{AUTHOR}

\section{CHRIS S. DUVALL}

Chris S. Duvall, duvall@unm.edu, is a Professor and Chair, Department of Geography and Environmental Studies, University of New Mexico, Albuquerque (USA). He recently published: - Duvall C.S., 2019. The African Roots of Marijuana. Durham, NC: Duke University Press.

- Duvall C.S., Butt B., Neely A.H., 2018. The trouble with savanna and other environmental categories, especially in Africa. In Lave R., Biermann C., Lane S. (eds.), Handbook of Critical Physical Geography. New York, Palgrave-Macmillan, p. 107-127

- Duvall C.S., 2017. Cannabis and Tobacco in Precolonial and Colonial Africa. In Oxford Research Encyclopedia of African History [Online]. DOI: https://dx.doi.org/10.1093/acrefore/

9780190277734.013.44 